\title{
NAS ENTRELINHAS DOS RELATOS HISTÓRICOS* \\ REFLEXOS DA FACULDADE DE DIREITO DO LARGO DE SÃO FRANCISCO \\ NO PROCESSO PELA LIBERTAÇÃO DOS ESCRAVOS EM SÃO PAULO
}

\author{
HISTORICAL RECORD BETWEEN THE LINES. THE INFLUENCE OF LARGO DE SÃO FRANCISCO \\ LAW SCHOOL IN THE ABOLITION OF SLAVERY IN SÃO PAULO
}

Cristina Emy Yokaichiya*

\begin{abstract}
Resumo:
O presente artigo trata do processo de abolição na cidade de São Paulo, particularmente diante da criação da Faculdade de Direito do Largo de São Francisco. Para além da conhecida participação dos juristas da Academia no processo político e legislativo do País, busca-se destacar o panorama abolicionista social, cultural e intelectual construído na metrópole cafeeira paulista, em razão da presença dos estudantes, da aplicação do Direito de forma diferenciada em favorecimento dos escravos negros e, principalmente, do movimento de resistência encampado por Luiz Gama, com continuidade pelos Caifazes.
\end{abstract}

Palavras-chave: Escravidão. Abolicionismo. Escravos libertos. Faculdade de Direito do Largo de São Francisco. Insurreição.

\begin{abstract}
:
The article discusses slavery abolition in the city of São Paulo, focusing the role developed by Faculdade de Direito do Largo de São Francisco. Beyond the already known participation of law practitioners from the São Paulo Law School in the national political and legislative landscapes, the article highlights the social, cultural and intellectual colors of the abolitionism processes in the coffee-grower capital of São Paulo, which are the result of student activity, of law applied differentially in favor of black slaves and, above all, of the resistance movement led by Luiz Gama, and further aided by the Caifazes.
\end{abstract}

Keywords: Slavery. Abolitionism. Freed slaves. Faculdade de Direito do Largo de São Francisco. Insurrection.

1. Introdução

O presente artigo busca enfatizar alguns aspectos contidos nas entrelinhas dos relatos históricos sobre o processo de libertação dos escravos em São Paulo. Embora não tenha o destaque dos discursos abolicionistas proferidos no Parlamento ou dos projetos de lei

\footnotetext{
* Trabalho elaborado no Curso de História do Direito Penal brasileiro, ministrado pelos professores Miguel Reale Júnior e Janaína Conceição Paschoal, na Pós-Graduação da Faculdade de Direito da Universidade de São Paulo.

** Mestranda em Direito Penal pela Faculdade de Direito da Universidade de São Paulo.
} 
apresentados pelos grandes juristas do século XIX, a Faculdade de Direito do Largo de São Francisco contribuiu, com ações direta ou indiretamente relacionadas a atividades acadêmicas, com o avanço da causa abolicionista no debate público que antecedeu o fim do regime escravagista no Brasil.

Nesse sentido, pretende-se abordar, para além dos já conhecidos e exaltados posicionamentos antiescravistas assinalados no processo legislativo do país, a influência da criação dos cursos jurídicos em São Paulo na formação cultural, social e jurídica da comunidade local, direcionada à luta contra o trabalho servil negro.

Não se abordará, como fatores essenciais que desencadearam a promulgação da Lei Áurea, nem as insurreições dos escravos nem as medidas adotadas pelas elites esclarecidas da época a seu alvedrio. Dar-se-á ênfase aos elementos conjunturais de grande impacto social à época de transição da escravidão para a liberdade, entremeados ao funcionamento dos cursos jurídicos no Largo de São Francisco.

2. A realidade escravocrata paulista: as entrelinhas da descrição da cidade

"Cai, orvalho de sangue do escravo,

Cai, orvalho, na face do algoz.

Cresce, cresce, seara vermelha,

Cresce, cresce, vingança feroz".

(Trecho de Bandido Negro, do "poeta dos negros" Castro Alves)

São Paulo, à diferença do Rio de Janeiro e da Bahia, apresentou uma escravidão negra tardia. Isso porque, até o século XVIII, preponderou a utilização do trabalho indígena, propiciada pelos esforços de catequização levados a cabo pelos jesuítas desde a fundação da vila de São Paulo. Assim, a força negra atrelou-se à produção açucareira e cafeeira do Estado paulista, em maiores proporções, apenas ao longo do século XIX.

A cidade, inicialmente inexpressiva e provinciana, tornou-se então a metrópole do café. Com isso, a produção do interior paulista passou a concentrar um número crescente de escravos e, em 1870, representava uma das principais províncias negreiras do País.

O núcleo urbano da capital, contudo, possuía uma particularidade: a Faculdade de Direito do Largo de São Francisco. A criação dos cursos jurídicos na cidade transformou significativamente sua dinâmica social. Ernani Silva Bruno, em relato sobre a História e Tradições da Cidade de São Paulo, narra que o primitivo arraial jesuítico, entre os anos de 1828 a 1872, adquiriu nova cor com a presença dos estudantes, seus criados e cozinheiras, que formaram "como uma sociedade à parte dentro da população de São 
Paulo". ${ }^{1}$ Dispersos entre as linhas da descrição oficial da cidade, esses jovens acadêmicos dinamizaram o debate sobre a instituição da escravidão, alistando-se rapidamente nas brigadas de seus detratores, em que pese uma minoria sustentasse a imprescindibilidade da escravidão para o desenvolvimento nacional.

Diante da necessidade de formar a classe dirigente do país, responsável pela administração e pela condução política do Estado, ${ }^{2}$ o ensino nas Arcadas extrapolava a formação dogmática de advogados. A valorização da liberdade, que permeava a mentalidade dos estudantes, não advinha somente do desapego das rigorosas amarras do poder patriarcal, mas, principalmente, das bases filosóficas que informavam os conceitos fundamentais do Direito então ensinado.

Dentre as matérias ministradas na Academia, destacava-se a de Direito

Natural, que

caracterizava-se, grosso modo, pela idéia de que além ou acima do Direito que varia no tempo e no espaço, isto é, do Direito historicamente concebido, existiria um Direito inerente ao ser humano, inato, decorrente de sua própria natureza (racional) e que se manifestaria em qualquer agrupamento humano, não por convenção ou por arbítrio, mas pela natureza e pela razão. Cumpre ressaltar, ainda, que para Kant, um dos pensadores que mais influiu na filosofia jurídica, a liberdade seria o único direito inato do ser humano. Pode-se compreender aí a importância que podiam ter as teorias do Direito Natural na Academia de São Paulo, gestada na própria idéia de liberdade. ${ }^{3}$

Os estudantes da Província de São Paulo não eram, em sua plenitude, antiescravocratas. Também não se trata de afirmar que o conhecimento acadêmico os conduzia não apenas à condenação do trabalho braçal negro, mas à ampla difusão dessa repulsa. Ao contrário, apesar de existir um relevante movimento estudantil pela causa abolicionista, o pensamento escravista subsistia e se afirmava tanto na sociedade tradicional quanto

1 BRUNO, Ernani Silva. História e tradições da cidade de São Paulo. 4. ed. São Paulo: Hucitec, 1991. p. 808809. v. 4.

2 CARVAlHO, José Murilo de. A construção da ordem. Brasília: Editora Universidade de Brasília, 1981. v. 4, p. 177-183, aborda as limitações da intervenção das elites nos conflitos sociais, tendo em vista sua imbricação nos processos de condução do Estado brasileiro. À p. 179, o autor sintetiza essa tendência: “(...) pelo próprio fato de parte da elite estar vinculada ao Estado e pelo fato de que em sua maioria provinha de setores da classe dominante, os conflitos a que davam margem as divergências eram de natureza limitada. Os conflitos que extravasavam os parâmetros e apontavam na direção de um confronto aberto interclasse passavam à margem da elite nacional e circunscreviam-se às lideranças regionais ou locais". Pretende-se, neste artigo, analisar justamente as situações em que a participação de componentes da elite nos conflitos sociais era direta e alcançava efeitos nacionais.

3 MARTINS, Ana Luiza; BARBUY, Heloisa. Arcadas: história da Faculdade de Direito do Largo de São Francisco 1827-1997. São Paulo: Alternativa, 1998. p. 29. 
na comunidade acadêmica, como demonstra o relato de Alberto Venâncio Filho sobre o professor Veiga Cabral, ${ }^{4}$ da cadeira de Direito Civil:

Demonstrava ainda fortes preconceitos raciais, implicando com estudantes de cor, ao ponto de não permitir que lhe estendessem a mão. Consta-se que uma vez ofereceu o pé a um deles que o queria cumprimentar: - Desaforo: negro não pode ser doutor. Há tanta profissão apropriada: cozinheiro, cocheiro, sapateiro. ${ }^{5}$

Essa era a tendência da época: o preconceito. Ainda assim, embora o corpo discente proviesse também de outras regiões (nas primeiras turmas, do Rio de Janeiro, Minas Gerais, Bahia, Rio Grande do Sul, Maranhão e Mato Grosso), fortemente marcadas pelo uso da mão-de-obra escrava, a elite intelectual que se formava demonstrava arraigados vínculos com o ideário abolicionista. ${ }^{6}$

Mesmo em situações menos politizadas, verificam-se relatos de libertação ou pagamento de negros-acompanhantes, os quais seguiam os passos de seus senhores durante todo o tempo de estudos. Os escravos de estudantes formavam uma espécie de "subclasse" à sombra de seus senhores, paralela à comunidade acadêmica. Recebiam no ano de ingresso na Academia a denominação de "calouros", análoga à de seus senhores, o que os inseria em uma hierarquia liderada por "veteranos"; ao final do curso do estudante, era costumeira a alforria do escravo, com o recebimento da carta de liberdade por este concomitante ao diploma de bacharel daquele. ${ }^{7}$

O trabalho remunerado dos escravos ocorria para complementar os recursos que custeavam as repúblicas - os estudantes de famílias menos abastadas convertiam seus cativos em verdadeiros "escravos de ganho". Esse foi o caso do notório negro Ambrósio, que, em razão da idade, não conseguia mais realizar serviços braçais na fazenda e, por isso, utilizou seus dotes de quitandeiro para a confecção de biscoitos, bolos e doces, vendidos

\footnotetext{
4 Em abril de 1829 foi nomeado lente proprietário da cadeira de direito pátrio na academia de São Paulo, exercendo as funções de Diretor interino, nomeado diretor efetivo em 1843.

5 VENANCIO FILHO, Alberto. Das Arcadas ao bacharelismo: 150 Anos de Ensino no Brasil. São Paulo: Perspectivas, 1977. p. 41.

6 As manifestações retóricas dos estudantes são retratadas no livro Arcadas: "O então acadêmico José Bonifácio, o Moço contribuiu, em 1850, com uma das primeiras manifestações em verso contra a escravidão, através do poema Saudades do Escravo; em 1855, a Revista Mensal do Ensaio Filosófico publicava, de João Diogo de Menezes, Ao Escravo; no mesmo órgão, em 1858, Francisco Leite de Bittencourt Sampaio, que seria o autor de letra do Hino Acadêmico enquanto Carlos Gomes compunha a música, lançava a poesia Cativa" (grifos do original). (MARTINS, Ana Luiza; BARBUY, Heloisa. Arcadas: História da Faculdade de Direito do Largo de São Francisco 1827-1997. São Paulo: Alternativa, 1998. p. 76).

7 BRUNO, Ernani Silva. História e tradições da cidade de São Paulo. 4. ed. São Paulo: Hucitec, 1991. p. 820. v. 2 .
} 
inicialmente no Largo da Igreja da Misericórdia e, por fim, em uma venda de guloseimas, cujos lucros eram repartidos entre Bernardo Guimarães, seu dono, e ele. ${ }^{8}$

Com a presença de numerosos estudantes, São Paulo tornou-se um centro intelectual de produção variada, com revistas literárias, artigos jornalísticos e até poesia romântica, muitos de mote abolicionista. Composta de uma população relativamente pequena em comparação à Corte, ${ }^{9}$ a capital paulista forjou uma cultura própria, em que as discussões jurídicas eram significativas e acentuavam a tendência política liberal, especialmente dos mais jovens, egressos da Academia de Direito. Isso fez com que iniciativas abolicionistas variadas ganhassem uma legitimidade que, talvez, não pudessem alcançar em outro lugar, o que desembocou na extinção relativamente precoce da escravidão nesta região. ${ }^{10}$

\section{Nas palavras de Lígia Fonseca Ferreira}

aqueles futuros advogados, magistrados, jornalistas, administradores, professores ou políticos passavam a ter uma visão global do Brasil, abandonando o prisma regional que entravava a consolidação da independência e de um real sentimento ou idéia de nação. A variedade das regiões representadas nesse microcosmo inspiraria, assim, uma 'civilidade' mais 'cívica' do que a que talvez emanasse da corte, como escreve Gilberto Freyre no prefácio a História e tradições da cidade de São Paulo (Bruno, 1953, p. XIV). A mentalidade dos jovens membros das elites brasileiras impregna-se da 'educação liberal típica das faculdades de direito brasileiras', onde adquirem uma concepção nova dos problemas do país do qual um dia muitos virão a ser os dirigentes (Adorno, 1988). ${ }^{11}$

O novo e arejado ambiente do pequeno burgo paulista compunha-se, pois, de uma mescla de influências e declarações. Os choques de pensamento encontravam seu auge no encontro, ora conflitivo, ora complementar, entre os estudantes e os antigos habitantes de São Paulo. Essa nova dinâmica, aos poucos, conformou uma configuração ideológica diferente na cidade. A importância da educação, por exemplo, fazia com que

\footnotetext{
8 Vida e Obra de Bernardo Guimarães - poeta e romancista brasileiro [1825-1884 - biografia] <http://www. geocities.com/athens/olympus/3583/ambrosio.htm> Última consulta em 11/12/2008.

9 Esclarecem Roger Bastide e Florestan Fernandes que "em 1854, a cidade com seu termo rural compreenderia 31.824 habitantes, dos quais 23.834 seriam livres, 7.068 escravos e 922 estrangeiros" (BASTIDE, Roger; FERNANDES, Florestan. Brancos e negros em São Paulo. 4. ed. São Paulo: Global, 2008. p. 60).

${ }^{10}$ MACHADO, Maria Helena Pereira Toledo. História e Historiografia da Escravidão e da Abolição em São Paulo. In: FERREIRA, Antonio Celso; LUCA, Tânia Regina de; IOKOI, Zilda Grícoli (Orgs.). Encontros com a História: percursos históricos e historiográficos de São Paulo. São Paulo: UNESP, 1999. p. 69.

${ }^{11}$ FERREIRA, Lígia Fonseca. Luiz Gama: um Abolicionista leitor de Renan. Estudos Avançados, São Paulo, v. 21, n. 60, p. 271-288, maio/ago. 2007. p. 273.
} 
vários fazendeiros paulistas e significativos representantes das agitações abolicionistas defendessem a necessidade de educar o liberto para transformá-lo em trabalhador livre:

não escapara à aguda percepção de alguns dos seus líderes intelectuais que o trabalhador negro, recém regresso da escravidão e por ela deformado, não estava em condições de resistir à livre competição com o imigrante europeu. ${ }^{12}$

Não por razão diversa Rui Barbosa lançava seu projeto de educação popular, propondo alfabetização e instrução básica para os escravos e a criação de escolas de primeiras letras para os desvalidos, condição indispensável para sua efetiva libertação.

A ação dos estudantes também provocava realidade diversa em São Paulo, em comparação a outras cidades do País, já que a militância abolicionista criava um manto de proteção dos escravos, seja de forma legal, com as ações de liberdade, seja pelas redes de solidariedade formadas pela articulação de seus diversos clubes de advogados, jornalistas, centros abolicionistas e lojas maçônicas. ${ }^{13}$ A capital tinha não-só uma nova geografia de idéias, mas uma intensa arquitetura de medidas e manifestações.

Há de se ressaltar que a atuação dos juristas a partir de São Paulo, formados em sua imensa maioria pela Faculdade de Direito do Largo de São Francisco, foi muito relevante para o fim da escravidão. Obviamente, essa não foi uma variável isolada, nem o eixo fundamental das lutas abolicionistas. Mas se inscreveu com peso na convergência de atuações que definiu a abolição - o reordenamento político das elites paulistas e após nacionais, os movimentos abolicionistas e as revoltas dos escravos - compondo o quadro de transformações sociais no País, na década de 1880.

3. A perspicácia jurídica: as entrelinhas da legislação

As reformas legislativas com o fito de atenuar a escravidão ocorreram de forma lenta e gradual. O ingresso de negros no Brasil, em decorrência do tráfico de escravos africanos, foi inicialmente proibido por tratado firmado com a Inglaterra em 1826. Posteriormente, a mesma determinação foi reiterada pela Lei Eusébio de Queiroz, em 1850 .

${ }_{12}$ BASTIDE, Roger; FERNANDES, Florestan. Brancos e negros em São Paulo. 4. ed. São Paulo: Global, 2008. p. 66.

${ }_{13}$ No enterro da respeitado advogado Luiz Gama, por exemplo, Raul Pompéia aponta as homenagens do Centro Abolicionista, da Caixa Emancipadora Luiz Gama, da Loja América, da Loja Sete de Setembro, da Sociedade Quatorze de Julho, do Clube dos Girondinos, da Gazeta do Povo, do Comércio de São Paulo, do Clube Ginástico Português e outros (POMPÉIA, Raul. Última página da vida de um grande homem. Gazeta de Notícias, em 10 de setembro de 1882. In: SILVA, Edmar et al. Luiz Gama: poeta e cidadão, memória da luta negra em São Paulo. São Paulo: Prefeitura Municipal - Coordenadoria Especial dos Assuntos da População Negra, 2003. p. 39). 
Todas as medidas relacionadas ao processo legislativo demonstraram um caráter, em certa medida, conservador, em que a liberdade era conferida a conta-gotas. As reformas propostas por José Antonio Pimenta Bueno, convocado pelo imperador em 1865, não ambicionavam a abolição radical dos escravos, mas criavam mecanismos de eliminação paulatina da servidão negra, sem alterações bruscas no sistema de trabalho então predominante no Brasil.

Entre a Lei do Ventre Livre (1871) e a Lei dos Sexagenários (1885), mais de 13 anos se passaram. A indignação dos juristas da época com a insuficiência das reformas tomou vulto com a eloqüência de Rui Barbosa, que em sua "Apreciação Geral da Reforma" denunciou a timidez da lei, de 1871

longe de constituir a definitiva satisfação dada ao movimento abolicionista, era apenas, na jornada redentora, um ponto de espera por breve espaço de tempo (...) Como, pois, aqui, treze anos depois, ainda nos havemos de satisfazer com essa medida preambular? ${ }^{14}$

Antes da edição da Lei Áurea, que consagrou tardiamente o fim da abolição, os juristas utilizaram, durante o longo período de reformas legais pontuais, recursos interpretativos e mecanismos jurídicos sagazes para adaptar o ordenamento à realidade pós-escravidão. Dada a dificuldade de as leis acompanharem os anseios abolicionistas, passou-se a afastar uma visão meramente instrumental e dogmática do direito, que cedeu espaço a uma aplicação declaradamente política e condizente com a realidade social.

As lacunas enxergadas no regramento jurídico davam azo à criação de normas costumeiras. Destaca Manuela Carneiro de Cunha que existia a praxe, ao exclusivo talante do senhor de escravos, de conceder ou negar alforrias, "por oferta do valor" do negro, ainda que à revelia do Estado, porque não havia previsão legal antes da Lei do Ventre Livre. ${ }^{15}$

Ainda sobre as entrelinhas da lei, afirma a Autora que

o que vem subentendido nestas práticas é a existência, também silenciada na lei até 1871 , mas plenamente vigente no direito costumeiro, do pecúlio do escravo. Se de jure o escravo não podia possuir coisa alguma, de facto chegava-

\footnotetext{
${ }_{14}$ BARBOSA, Rui. Emancipação dos escravos: Projeto Dantas (dos Sexagenários) e o Parecer que o Justifica. In: Obras Completas de Rui Barbosa. Rio de Janeiro: Fundação Casa de Rui Barbosa, 1998. p. 215-216.

${ }^{15}$ CUNHA, Manuela Carneiro da. Antropologia do Brasil: Mito, História, Etnicidade. São Paulo: Brasiliense, 1986. p. 129: “o Aviso de 1831 terá aberto um campo de especulações sobre o direito de alforria que só será estancado com o parecer peremptório da seção de Justiça do Conselho de Estado, em 1855. Este parecer de um órgão assessor do Imperador, fortemente reacionários nesse período, põe cobro a 'interpretações humanitárias de leis estabelecidas', e reafirma que não há lei que obrigue o senhor a alforriar seu escravo".
} 
se por exemplo a ter forma especiais de se marcar o gado pertencentes aos escravos. ${ }^{16}$

Do mesmo modo, constata-se a existência de construções jurisprudenciais importantes, como qualificar como liberto o escravo que comprovasse "viver sobre si", ou seja, ter moradia urbana independente dos meios financeiros do senhor. A autorização do senhor para o escravo morar fora de casa, pagando seu próprio aluguel e alimentação, representava praticamente a liberdade, ${ }^{17} \mathrm{o}$ que foi confirmado pelos tribunais em algumas ocasiões.

Outras construções jurídicas surgiram como meio de controlar a excessiva arbitrariedade escravista da época, como a situação do status liber decorrente da Lei do Ventre Livre. "O statuliber é juridicamente aquele cuja liberdade está estatuída ou destinada a ser-lhe conferida em um certo tempo, ou mediante certa condição". ${ }^{18} \mathrm{Na}$ situação de quase-liberto, não se podia admitir a aplicação da pena cruel de açoite, considerada odiosa e obsoleta, ainda que as leis de 1871 e 1885 houvessem silenciado sobre esse assunto.

Observa-se a importância da jurisprudência ainda na definição das regras aplicáveis aos atos civis e criminais dos libertos. Na ausência de um "Code Noir", voltado exclusivamente para os negros, utilizavam-se institutos do Código Criminal, de 1830, e dispositivos das leis do Ventre Livre e do Sexagenário para regular as relações dos negros. Desse modo, os juristas - e principalmente os juízes - passaram a assumir um papel central na definição dos direitos dos escravos negros e dos libertos. ${ }^{19}$

Além das estratégias correntes de tomar a verdadeira idade do cativo ou a alegação de filiação ignorada para sustentar a ilegalidade do cativeiro, os juristas apresentavam aos tribunais valores irrisórios com vistas a "adquirir" a liberdade dos escravos submetidos a maus tratos ou fugidos, conforme mecanismos da Lei do Ventre Livre, o que abria a oportunidade para a colaboração dos membros do Poder Judiciário simpáticos à causa abolicionista, como escrivães, avaliadores, arbitradores ou angariadores de contribuições pecuniárias. ${ }^{20}$ Assim,

\footnotetext{
${ }^{16}$ CUNHA, Manuela Carneiro da. Antropologia do Brasil: Mito, História, Etnicidade. São Paulo: Brasiliense, 1986. p. 127.

${ }^{17}$ CHALHOUB, Sidney. Visões da Liberdade: uma história das últimas décadas da escravidão na corte. São Paulo: Companhia das Letras, 1990. p. 236-239.

${ }_{18}$ NEQUETE, Lenine. O Escravo na Jurisprudência Brasileira: Magistratura e Ideologia no Segundo Reinado. Porto Alegre: Tribunal de Justiça do Rio Grande do Sul, 1988. p. 18-21.

${ }^{19}$ MACHADO, Maria Helena Pereira Toledo. História e historiografia da escravidão e da abolição em São Paulo. In: FERREIRA, Antonio Celso; LUCA, Tânia Regina de; IOKOI, Zilda Grícoli (Orgs.). Encontros com a História: percursos históricos e historiográficos de São Paulo. São Paulo: UNESP, 1999. p. 68-69.

${ }^{20}$ MACHADO, Maria Helena. O plano e o pânico: os movimentos sociais da década da abolição. São Paulo: EDUSP, 1994. p. 152.
} 
na São Paulo dos anos de 1880, embora a chamada atuação legal se fizesse presente há muito, e por isso marcante, conflitos de rua e forte participação popular se notabilizaram. Extensão radicalizada da luta jurídica empreendida, desde os primórdios da década de 70, por jurisconsultos, nas barras de diversos tribunais, sobretudo nos da cidade de São Paulo, o movimento abolicionista, em sua feição paulistana, teve sua origem mais marcante no legalismo dos advogados abolicionistas. Utilizando-se das brechas abertas tanto pela lei 1831, que passava a considerar ilegal a escravidão dos africanos e descendentes, entrados no país após esta data, quanto pela de 1871, que institucionalizava os pecúlios e a arbitragem judicial do valor do escravo nos casos de conflito, muitos advogados e oficiais de justiça passaram a dedicar-se à defesa gratuita dos cativos. ${ }^{21}$

4. Nas entrelinhas das listas de alunos da Faculdade de Direito de São Paulo

"Miseráveis; ignoram que mais glorioso
é morrer livre numa forca, ou dilacerado
pelos cães em praça pública, do que
banquetear-se com os Neros na escravidão"
(Carta de Luiz Gama a Ferreira de Menezes)

Normalmente, ao tratar da atuação dos acadêmicos no movimento da abolição, costuma-se indicar importantes juristas como Pimenta Bueno, Rui Barbosa ou Joaquim Nabuco. Contudo, embora não conste nas relações oficiais de ex-alunos da Faculdade de Direito de São Paulo, outro importante ator que se beneficiou dos ensinamentos jurídicos da Academia foi Luiz Gonzaga Pinto da Gama.

Filho de valente africana livre, Luiza Mahin, Luiz Gama nasceu no dia 21 de julho de 1830, na Bahia. Seu pai, fidalgo português, endividou-se no jogo e, em 1840, vendeu seu próprio filho a um traficante de escravos.

Após ser vendido aos 10 anos de idade, Luiz Gama foi enviado da Bahia para o Rio de Janeiro e, posteriormente, a São Paulo, onde trabalhou para o alferes Antonio Pereira Cardoso. Por sorte, o jovem Antonio Rodrigues do Prado Júnior ensinou-lhe as primeiras letras e, passado um ano, já conseguia ler e expressar-se por escrito.

Escapando do cativeiro com provas de sua condição livre, obtidas "ardilosa e secretamente", ${ }^{22}$ iniciou-se, aos 17 anos, na Marinha de Guerra, onde alcançou o posto

\footnotetext{
${ }^{21}$ MACHADO, Maria Helena. O plano e o pânico: os movimentos sociais da década da abolição. São Paulo: EDUSP, 1994. p. 151.

${ }^{22}$ GAMA, Luiz. Autobiografia de Luiz Gama. Apresentação de Roberto Schwarz. Novos Estudos, n. 25, out. 1989. p. 140.
} 
de cabo de esquadra, até ter a patente rebaixada por se haver insurgido contra um oficial que o insultara.

São raras as narrativas sobre a escravidão escritas pelos próprios ex-escravos, alheios ao privilégio da educação letrada, restrita à elite. Não se pode olvidar, porém, a importância das publicações de libertos como Gama, cuja prolífica produção inclui uma coletânea de poemas líricos, de sátira social e política, Primeiras Trovas Burlescas (1860), diversos artigos publicados em periódicos como Diabo Coxo (1864-1865) e Cabrião (1866-1867). A presença de Gama na Imprensa paulistana era freqüente e explosiva.

Na São Paulo dos letrados da época, acadêmicos e advogados, Luiz Gama conquistou seu espaço. O conhecimento proveniente da Academia de Direito não gerou efeitos somente àqueles que freqüentaram suas salas de aula. Embora tenha sido repelido em sua tentativa de se matricular na escola jurídica, Gama usufruiu indiretamente de suas lições, conforme declara em sua carta autobiográfica enviada a Lucio de Mendonça:

Durante o meu tempo de praça, nas horas vagas, fiz-me copista; escrevia para o escritório do escrivão major Benedito Antonio Coelho Neto, que tornou-se meu amigo; e que hoje, pelo seu merecimento, desempenha o cargo de oficial-maior da Secretaria do Governo e, como amanuense, no gabinete do exmo. sr. conselheiro Francisco Maria de Souza Furtado de Mendonça, que aqui exerceu, por muitos anos, com aplausos e admiração do público em geral, altos cargos na administração, polícia e judicatura, e que é catedrático da Faculdade de Direito, fui eu seu ordenança; por meu caráter, por minha atividade e por meu comportamento, conquistei a sua estima e a sua proteção; e as boas lições de letras e de civismo, que conservo com orgulho. ${ }^{23}$

A proximidade com seu amigo e protetor Furtado de Mendonça, professor e bibliotecário-chefe da Faculdade de Direito, permitiu a Gama sua evolução no universo jurídico. No entanto, por não ter sido formado pela Faculdade de Direito do Largo de São Francisco, o autodidata tornou-se "advogado rábula", com uma licença especial para exercer a profissão (permitida a pessoas que comprovassem competências na matéria jurídica).

A partir de então, utilizou-se da Imprensa e da tribuna como palcos para a defesa de seus ideais. Luiz Gama exercia a advocacia exclusivamente em prol da causa da libertação da imensa população de negros escravos, o que lhe consumia todo o tempo. A baixa lucratividade de seu negócio, especializado em causas de alforria, não era motivo para desânimo, nem para refutar o patrocínio gratuito de ações de liberdade.

${ }^{23}$ GAMA, Luiz. Autobiografia de Luiz Gama. Apresentação de Roberto Schwarz. Novos Estudos, n. 25, out. 1989. p. 141 
Entusiasta de um abolicionismo militante, Gama projetou sua fama como orador impetuoso, levando às Cortes as injustiças da exploração da sua gente. Narra Antonio Manoel Bueno de Andrada que os combates forenses desse jurista emocionavam a opinião pública, descrevendo um de seus feitos:

Falecera em Santos, no correr do ano de 1871, um milionário português - o Neto. $\mathrm{O}$ inventário deu motivo à importante demanda entre herdeiros e sócios comerciais. Do espólio constava a existência de cento e tantos escravos. Luiz Gama, baseado não sei em quê, interveio no litígio, pleiteando a libertação dos cativos. A luta travou-se, tenaz e exhaustiva, produziu enorme escândalo, mas ele venceu. Da sua estrondosa vitória, na célebre 'causa Neto', decorreram duas conseqüências. O número de pleitos dessa natureza cresceu com rapidez. Todos entregues ao grande defensor dos oprimidos. Ele nunca recusou um, siquer! E, de triunfo, o advogado liberal conseguia baratear extraordinariamente $o$ custo das 'cartas de liberdade'. ${ }^{24}$

Consta que, nesse caso, Luiz Gama rivalizou no Tribunal do Júri com o renomado orador José Bonifácio, “o Moço” e, com argumentos jurídicos contrários à ordem tradicional vigente, conseguiu vencê-lo. ${ }^{25}$

Embora muitos estudantes participassem da luta pela abolição, inexistia um posicionamento institucional da Academia acerca do tema. As atuações, no campo jurídico, nas publicações da época e mesmo nas insurreições armadas, eram eminentemente isoladas. No caso específico de Luiz Gama, seu prestígio e coerência com a causa abolicionista conseguiram agregar tanto advogados quanto outras pessoas da sociedade (normalmente colaboradores com despesas de campanha, como compra de alforrias e custeio de ações judiciais, que, em geral, auxiliavam a saldar os compromissos forenses do abolicionismo). Destacam-se nesse grupo outros abolicionistas formados na Faculdade de Direito do Largo de São Francisco, cujo potencial foi descrito no testemunho de Antonio Andrada:

na tribuna judiciária, a eloqüência de Fernandes Coelho
e de Rubem Cesar não encontrava rival entre advogados
adversários. Muitos outros secundaram as pugnas
inolvidáveis do intemerato Luiz Gama, mas os acima citados,
com meu respeito e saudade, e mais o Mercês, simpática
tradição acadêmica da Faculdade de Direito, formavam o
que o público chamava - a roda de Luiz Gama. ${ }^{26}$

\footnotetext{
${ }^{24}$ ANDRADA, Antonio Manuel Bueno de. Depoimento de uma Testemunha. Revista do Instituto Histórico e Geográfico de São Paulo, São Paulo, v. 36, 1939. p. 210.

${ }^{25}$ SANTOS, Francisco Martins dos. História de Santos. 2. ed. São Vicente: Caudex, 1986. p. 220.

${ }^{26}$ ANDRADA, Antonio Manuel Bueno de. Depoimento de uma testemunha. Revista do Instituto Histórico e Geográfico de São Paulo, São Paulo, v. 36, 1939. p. 214.
} 
Valendo-se desse prestígio, o advogado negro fundou, ao lado de Rui Barbosa, a ativíssima loja maçônica "América", que passou a agregar muitos estudantes, tornando-se o berço do anteprojeto para a emancipação das crianças escravas, apresentado ao Parlamento, em 1869.

Todas as oportunidades para a defesa dos negros eram utilizadas por esses advogados nos tribunais. A questão jurídica normalmente levantada por Gama estava calcada na vigência da Lei de 7 de novembro de 1831, que havia declarado livres todos os africanos trazidos ao País após aquela data. Fábio Konder Comparato contextualiza que

enquanto magistrados covardes, cedendo à pressão dos fazendeiros, se recusavam a aplicá-la, o governo multiplicava exigências burocráticas para a soltura dos negros criminosamente mantidos no cativeiro e a Assembléia Geral votava leis destinadas a esvaziar toda força normativa da lei, embora mantendo-a formalmente em vigor. Em suma, era a velha tática brasileira de cobrir a dominação oligárquica com as vestes ornamentais do "Estado de Direito". Para nós, desde a Independência, a Constituição, os tratados internacionais e as leis votadas no Parlamento sempre foram recebidas como as ordenações d'El Rei, nosso senhor durante o período colonial: respeitosamente acatadas, mas não cumpridas. ${ }^{27}$

Luiz Gama esclarecia, por meio da Imprensa, que

as vozes dos abolicionistas têm posto em relevo um fato altamente criminoso e assaz defendido, há muitos anos, pelas nossas indignas autoridades. É o fato de que a maior parte dos escravos africanos existentes no Brasil foram importados depois da lei proibitiva do tráfico promulgado em [7 de novembro de] 1831. Começam[,] amedrontados pela opinião pública, os possuidores de africanos livres a vendê-los para lugares distantes dos de sua residência. $\mathrm{Da}[. .$.$] província de$ Minas Gerais, acaba, um Sr. Antonio Gonçalves Pereira, de enviar para esta província os africanos Jacinto e sua mulher para serem aqui vendidos, isto porque é ali sabido e muito se falava ultimamente, que tais africanos foram importados há 20 anos!... Podemos afirmar que em idênticas circunstâncias existem muitos africanos nesta cidade, com conhecimento das autoridades, que são as principais protetora[s] de crime tão horroroso. ${ }^{28}$

${ }^{27}$ COMPARATO, Fábio Konder. Luiz Gama, herói do povo brasileiro. Folha de S. Paulo, São Paulo, 15 maio 2007. Disponível em: <http://www.oabsp.org.br/noticias/2007/05/15/4168/>. Acesso em: $11 \mathrm{dez} .2008$.

${ }^{28}$ Artigo de Luiz Gama publicado no periódico Radical Paulistano,em 30.9.1869, apud FERREIRA, Lígia Fonseca. Luiz Gama: um Abolicionista leitor de Renan. Estudos Avançados, São Paulo, v. 21, n. 60, p. 271288, maio/ago. 2007. p. 273. 
Diante da dificuldade de os senhores provarem a data de entrada de seus escravos no País, Gama reivindicava a liberdade destes em juízo. Da mesma forma, defendia aqueles que, possuindo o montante pecuniário necessário para comprar sua alforria, esbarravam com a intransigência de seus senhores, que não a queriam aceitar.

Com competência e indignação, Luiz Gama, perante os tribunais e sob a égide da legalidade, esclareceu em determinada ocasião que, quanto aos míseros escravos "em número superior a 500, tenho arrancado às garras do crime"29 - rótulo sob o qual tratava a nefasta escravidão. Segundo Américo Palha, de forma corajosa, no Tribunal do Júri, Luiz Gama brandiu a célebre frase "aquele negro que mata alguém que deseja mantêlo escravo, seja em qualquer circunstância, mata em legítima defesa!". 30

$\mathrm{O}$ êxito e a fama do advogado negro atraíram escravos de outras províncias para a capital paulista, que encontravam a acolhida dada por Gama até mesmo em sua própria casa, ou na rede de solidariedade montada pelos membros da Loja América. Assim, centenas de negros encontraram sua sorte na pena e na oratória do rábula, ex-escravo Luiz Gama.

$\mathrm{Na}$ Imprensa, o ex-escravo também denunciava a degradação e o abuso do ser humano inerentes à manutenção da instituição da escravidão. Partindo de perspectiva humanista e igualitária, Luiz Gama não podia admitir os argumentos econômicos e culturais em defesa da escravidão, fundados na desigualdade entre os homens e em conceitos de inferioridade e superioridade aplicados às relações sociais.

Novamente, nas colunas do Radical Paulistano, apontava rotineiramente os erros jurisprudenciais cometidos pela magistratura mal preparada:

$\mathrm{O}$ estólido juiz, porém, resolveu a questão indeferindo o requerimento, e mandando vender em hasta pública o peticionário, quando ele já não era escravo!... Esta lamentável ocorrência é nada menos que um grave atentado, cometido bruscamente pela autoridade ignorante, contra uma vítima desprotegida. É mais uma prova eloqüente, exibida, em nome do bom senso revoltado, contra o fatal sistema de confiar-se cargos de judicatura a pessoas nimiamente ignorantes, despidas até dos mais comesinhos rudimentos de direito, como é seguramente o Sr. Florêncio Soares Muniz, suplente do juízo municipal no Belém de Jundiaí. (...) patentear, diante do público judicioso, a completa incapacidade intelectual desse cidadão para o desempenho de importantíssimas funções inerentes à magistratura. ${ }^{31}$

${ }^{29}$ GAMA, Luiz. Autobiografia de Luiz Gama. cit., p. 141.

${ }^{30}$ AMÉRICO, Palha. Dez estadistas do Império. Rio de Janeiro: Serviço de Documentação do MTPS, 1961.

${ }^{31}$ GAMA, Luiz. Foro de Belém de Jundiaí. Radical Paulistano, em 30 de setembro de 1869. In: SILVA, Edmar et al. Luiz Gama: poeta e cidadão, memória da luta negra em São Paulo. São Paulo: Prefeitura Municipal - 
É de se notar que a opção abolicionista seguida por Luiz Gama foi bem diferente daquela estritamente parlamentar dos muitos filhos da Faculdade de Direito do Largo de São Francisco. O ex-escravo, entretanto, não viu o resultado mais intenso de seus esforços; a Lei Áurea foi promulgada anos após sua morte.

Em 1882, São Paulo parou para acompanhar o enterro de Luiz Gama, o "amigo de todos", ${ }^{32}$ líder do movimento que tornou a emancipação dos negros inevitável. Tido como o maior funeral ocorrido na cidade de São Paulo, congregou a mais variada classe de pessoas, desde escravos libertos a membros da elite letrada, passando inclusive por inúmeros escravocratas contrários a sua causa.

O estudante Raul Pompéia publicou, na Gazeta de Notícias, a homenagem "Última Página da Vida de um Grande Homem":

Luiz Gama fazia tudo: libertava, consolava, dava conselhos, demandava, sacrificava-se da própria vida as trevas do desespero daquele povo de infelizes, sem auferir uma sombra de lucro, entendendo que advogado não significa o indivíduo que vive dos jantares que lhe paga Têmis; entendendo que deve-se fazer um pouco de justiça grátis. E, com esta filosofia, empenhava-se de corpo e alma, fazia-se matar pelo bem. O herói...

Pobre, muito pobre, deixava para os outros tudo o que lhe vinha das mãos de algum cliente mais abastado; doente, moribundo, encontrava no âmago da sua natureza uma reserva instintiva de energia, e ia gastá-la em proveito da justiça e da beneficência oculta, avessa à fanfarra das reclames, sublime. Tudo isto conglobava-se-me no espírito, como uma grande esfera de luz, sobre a qual levantava-se a figura nobre, irresistível do bom Luiz Gama. Havia para ele como que um trono em minha alma. ${ }^{33}$

O incansável lutador viveu para os outros: não acumulava dinheiro, não cuidava de sua própria saúde. Esgotou-se até seus últimos dias no escritório, de onde encampava as infinitas demandas por liberdade. Na extrema pobreza, Luiz Gama acreditava na justiça pelo direito, que para ele não representava apenas uma profissão, mas o instrumento para cumprir a missão altruísta "contra a imoralidade e o poder". ${ }^{34}$

Coordenadoria Especial dos Assuntos da População Negra, 2003. p. 26.

32 Raul Pompéia esclarece que o advogado Luiz Gama era conhecido como o "amigo de todos" (POMPÉIA, Raul. op. cit.)

33 POMPÉIA, Raul. op. cit., p. 32-33.

${ }^{34}$ GAMA, Luiz. Pela última vez. cit., p.28. 
5. A ação dos caifazes: nas entrelinhas da descrição de justiça

Que acabe tudo em paz,

Assim é!

Viva, pois, qualquer caifaz

Olaré!

(Canção abolicionista do quilombo de Santos)

O falecimento de Luiz Gama gerou, além de marcante comoção popular, uma preocupação política. Os que ansiavam pela manutenção da luta abolicionista não vislumbravam uma figura que poderia

\begin{abstract}
identicamente, desempenhar seus humanitários encargos. Nenhum abolicionista reunia, naquele triste momento, a soma de requisitos para, nas lutas judiciárias e nas outras esferas, defender, com igual proveito, a causa de liberdade. Um possuíam (sic) prática forense; outros, a mesma dedicação; este conhecia o meio e gozava de simpatias; aquele dispunha de tempo; porém, em nenhum se enfeixavam as peregrinas qualidades do chefe. ${ }^{35}$
\end{abstract}

O possível vácuo na liderança dos fervorosos adeptos do abolicionismo abalou a comunidade que se reuniu ao redor do cadáver do condutor do movimento paulista. A multidão, sensibilizada pelo heroísmo do falecido, jurou que a campanha deveria prosseguir até a vitória final.

Nesse momento, Antonio Bento de Souza e Castro assumiu um papel fundamental nas lutas abolicionistas. Advogado formado na Faculdade de Direito do Largo de São Francisco, ex-promotor público e juiz municipal em São Paulo, não optou por substituir o grande patrono dos cativos na área judiciária. Antonio Bento transportou o foco dos esforços antiescravagistas, abandonando a "esfera restrita" do direito e partindo para as agitações revolucionárias.

Além da criação do jornal Redenção, Antonio Bento organizou um grupo de ativistas da causa abolicionista, que promoveria a fuga de milhares de escravos e desorganizaria a produção agrária paulista, fortemente dependente da força braçal negra.

Maria Helena Machado afirma existirem dúvidas e suspeitas sobre a efetiva participação de grupos organizados da elite paulista nas revoltas dos negros. Os chamados "caifazes" adotavam medidas extralegais de libertação, mas permaneciam no anonimato, comprazendo-se com as entrelinhas dos relatos históricos.

Entretanto, com o levantamento dos depoimentos e reminiscências dos antigos militantes, foi possível observar que

\footnotetext{
${ }^{35}$ ANDRADA, Antonio Manuel Bueno de. op. cit., p. 214.
} 
apenas a partir de 1887, com a penetração do abolicionismo nas senzalas, organizando as fugas em massa e o abandono das fazendas, é que o protesto dos escravos, antes de caráter imediatista e assistemático, ganhara um conteúdo e direção política efetivos. ${ }^{36}$

Se Luiz Gama atuava no campo jurídico, nos tribunais, os caifazes realizavam ações de disputa pela opinião pública e atividades despudoradamente ilegais. Não se pretende afirmar que todas as rebeliões foram coordenadas ou sugeridas pela elite, sendo os escravos parte inerte nesse processo; quer-se apenas indicar que o conhecimento jurídico e a organização estratégica dos abolicionistas paulistas foram relevante suporte para o esvaziamento das senzalas paulistas. ${ }^{37}$

Condutas que contornavam a lei, de fato, aproveitavam as insuficiências institucionais das polícias e dos tribunais do século XIX. Assim, fugas em grandes multidões, em conjunto com a desordem dos trabalhos nas fazendas, confundiam e dificultavam a repressão e, eventualmente, o julgamento dos atos ilícitos perpetrados. A impunidade gestada por estudantes de Direito e juristas experientes driblava os meios coercitivos, que se encontravam desgastados e ultrapassados para lidar com movimentos coletivos organizados.

Coordenado por Antonio Bento, o movimento enviava emissários (caixeiros viajantes), apelidados de "cometas", ao interior da Província de São Paulo, que, simulando visitas comerciais, entravam em contato com os escravos das fazendas, incitando-os a se rebelar e a iniciar fugas, e lhes garantindo recursos para as viagens e refúgios.

A subtração de escravos, pela ação dos abolicionistas, de fazendas e chácaras era meticulosamente planejada: os cálculos levavam em conta o terreno, o momento apropriado, a participação de auxiliares e, até mesmo, eventual conflito com capitães do mato responsáveis pela guarda dos cativos.

$\mathrm{O}$ movimento dos caifazes estava consideravelmente ligado à manutenção do quilombo Jabaquara de Santos. Como era cada vez maior o número de foragidos em São Paulo, tornava-se gradativamente mais difícil escondê-los das buscas policiais. Por essa razão, a existência de um local seguro para enviá-los, como este quilombo, facilitava a ocultação.

\footnotetext{
${ }^{36}$ MACHADO, Maria Helena. O plano e o pânico: os movimentos sociais da década da abolição. São Paulo: EDUSP, 1994. p. 143.

${ }^{37}$ Carlos Escobar ressalta que "Muito antes do Dr. Antonio Bento, numa reunião de libertos e de estudantes, na qual tomei parte, ficou deliberada a desorganização do trabalho agrícola, pela fuga dos escravos. Mas, só o grande Dr. Antonio Bento teve a subida honra de executar esse programa, pelo menos dois anos depois dessa reunião" (relato inserido em SANTOS, Francisco Martins dos. História de Santos. 2. ed. São Vicente: Caudex, 1986. p. 231).
} 
A criação do quilombo de Jabaquara representou uma resistência negra planejada e uma participação ativa dos libertos na libertação de outros negros. Não se acatava o pensamento de que a transição do trabalho escravo para o livre seria fruto de uma liderança elitista, que conduziria, paternalmente, o escravo à liberdade.

Jabaquara era, cada vez mais, um símbolo de liberdade e um monumento ao direito das criaturas com seus milhares de negros alforriados e felizes... (...) Dali por diante, todo o trabalho dos abolicionistas de Santos consistiu em receber e proteger os refugiados de serra-acima, dando-lhes ainda colocação remunerada ou escápula para mais longe. ${ }^{38}$

A intensificação das fugas em massa, no final dos anos 1880, deixaram muitos fazendeiros em situação aflitiva. Com o intuito de minorar o prejuízo, os proprietários cafeeiros começaram a conceder alforria com cláusula de prestação de serviços por tempo determinado ${ }^{39}$ Por orientação de Antonio Bento, adotou-se então uma estratégia voltada à nova situação dos fazendeiros. No caso de terras abandonadas pelos escravos fujidos, propunha-se ao proprietário a utilização de negros retirados de outros donos, mediante pagamento de salário de 400 réis diários. Frente à necessidade de mão-de-obra, foram firmados muitos contratos dessa natureza; por isso mesmo, "a Lei 13 de maio encontrou mais de um terço das fazendas de São Paulo lavradas por escravos retirados de outras". ${ }^{40}$

o processo abolicionista em São Paulo foi marcado por forte pressão popular, por intensa movimentação dos escravos, pelo aumento da criminalidade escrava, pelas revoltas, pela crescente atuação abolicionista de caráter jurídico, na forma de ações de liberdade, na qual se notabilizou Luiz Gama. Embora existente em São Paulo desde fins da década de 1860, a luta de caráter jurídico ainda não foi plenamente considerada pelos historiadores de São Paulo. O que se pode observar, no entanto, é que, dada a precocidade do abolicionismo militante em São Paulo, foi esta localidade pioneira no desenvolvimento das estratégias que claramente conduziram as fases posteriores da luta abolicionista. ${ }^{41}$

\footnotetext{
${ }^{38}$ SANTOS, Francisco Martins dos. História de Santos. 2. ed. São Vicente: Caudex, 1986. p. 227.

${ }^{39}$ BASTIDE, Roger; FERNANDES, Florestan. Brancos e negros em São Paulo. 4.ed. São Paulo: Global, 2008. p. 68-69.

40 ANDRADA, Antonio Manuel Bueno de. op. cit., p. 217.

${ }^{41}$ MACHADO, Maria Helena Pereira Toledo. História e historiografia da escravidão e da abolição em São Paulo. In: FERREIRA, Antonio Celso; LUCA, Tânia Regina de; IOKOI, Zilda Grícoli (Orgs.). Encontros com a História: percursos históricos e historiográficos de São Paulo. São Paulo: UNESP, 1999. p. 67.
} 


\section{Conclusão}

A Faculdade de Direito do Largo de São Francisco, instalada na Província de São Paulo no ano de 1827, trouxe relevantes modificações à cartografia humana, cultural e ideológica, da região. Merecem destaque as intervenções de estudantes e juristas nas campanhas públicas a favor da abolição, no processo legislativo, enriquecido por propostas de advogados formados na Academia paulista, e nos tribunais, em que proliferavam as teses gestadas em meio aos ideais libertários da Faculdade. Apesar de serem lidos usualmente nas entrelinhas dos relatos históricos, os estudantes anti-escravistas alteraram o panorama social e cultural da cidade.

Ao exprimir a mentalidade abolicionista, os jovens acadêmicos proporcionaram um clima de igualdade e um ambiente favorável à proteção dos negros: africanos livres ou escravos alforriados circulavam com tranqüilidade pelas ruas paulistas, protegidos pela militância abolicionista. A ressonância dessas novas idéias propulsionou movimentos associativos, envolvendo estudantes e não-estudantes, contagiando a população paulistana com os conhecimentos filosóficos libertários proveniente das Arcadas.

As atividades contrárias à exploração da mão-de-obra negra escrava ecoavam ora na legalidade, pelas associações, Imprensa, campanhas jurídicas ou parlamentares, ora na ilegalidade, com a penetração nas fazendas, violenta ou sigilosa, diretamente junto aos maiores interessados pela liberdade.

Extrapolando o moroso processo legislativo, postulava-se que

num sistema escravocrata, o abolicionismo, ao invés de meramente reformar a legislação, pode trincar suas estruturas. Os valores que estruturam a mudança, revolucionários, podem romper as volúveis amarras da lei e da ordem. Alçar a justiça como norte das ações aponta uma decisão política. A política legislativa, condicionada, nem sempre é a opção digna viável. Ainda que se busque lugar no mais das vezes no campo do direito, certas afrontas à dignidade humana requerem reações violentas, sob o risco de se condenar de antemão, pela legalidade, saídas revolucionárias contra a escravidão. $^{42}$

Somente com a instalação dos cursos jurídicos em São Paulo foi possível a irrupção e a expansão de um movimento abolicionista articulado, identificado pela junção de lutas parlamentares, atividades forenses, campanhas jornalísticas, organização maçônica e forte mobilização popular, por vezes violenta, por vezes pacífica. As escolhas

\footnotetext{
42 ARBIX, Daniel do Amaral. Escravos da lei, escravos da ordem. Pátio, São Paulo, n. 89, 19 abr. 2004. p. 08 (grifos no original).
} 
pela legalidade e pela ilegalidade, instrumentalizadas por talentos jurídicos, devem muito à pulsante vida acadêmica das Arcadas.

São Paulo, dezembro de 2008.

\section{Referências}

AMÉRICO, Palha. Dez estadistas do Império. Rio de Janeiro: Serviço de Documentação do MTPS, 1961.

ANDRADA, Antonio Manuel Bueno de. Depoimento de uma Testemunha. Revista do Instituto Histórico e Geográfico de São Paulo, São Paulo, v. 36, p. 210-227, 1939.

ARBIX, Daniel do Amaral. Escravos da lei, escravos da ordem. Pátio, São Paulo, n.89, p. 7-8. 19 abr. 2004.

BARBOSA, Rui. Emancipação dos escravos: Projeto Dantas (dos Sexagenários) e o parecer que o Justifica. In: Obras Completas de Rui Barbosa. Rio de Janeiro: Fundação Casa de Rui Barbosa, 1998. p. 204-229.

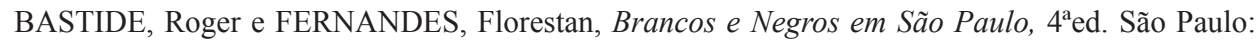
Global, 2008.

BRUNO, Ernani Silva. História e tradições da cidade de São Paulo. 4. ed. São Paulo: Hucitec, 1991. v. 2.

CARVALHO, José Murilo de. A construção da Ordem. Brasília: Editora Universidade de Brasília, 1981. v. 4.

CHALHOUB, Sidney. Visões da liberdade: uma história das últimas décadas da escravidão na Corte. São Paulo: Companhia das Letras, 1990.

COMPARATO, Fábio Konder. Luiz Gama, herói do povo brasileiro. Disponível em: <http://www. oabsp.org.br/noticias/2007/05/15/4168>. Acesso em: 11 dez. 2008.

CUNHA, Manuela Carneiro da. Antropologia do Brasil: Mito, História, Etnicidade. São Paulo: Brasiliense, 1986.

FERREIRA, Lígia Fonseca. Luiz Gama: um Abolicionista leitor de Renan. Estudos Avançados, São Paulo, v. 21, n. 60, p. 271-288, maio/ago. 2007.

GAMA, Luiz. Autobiografia de Luiz Gama. Apresentação de Roberto Schwarz. Novos Estudos, n. 25, p. 136-141, out. 1989.

. Foro de Belém de Jundiaí. In: SILVA, Edmar, et al. Luiz Gama: poeta e cidadão, memória da luta negra em São Paulo. São Paulo: Prefeitura Municipal - Coordenadoria Especial dos Assuntos da População Negra, 2003. p. 26. 
. Pela última vez. In: SILVA, Edmar, et al. Luiz Gama: poeta e cidadão, memória da luta negra em São Paulo. São Paulo: Prefeitura Municipal - Coordenadoria Especial dos Assuntos da População Negra, 2003. p. 27-28.

MACHADO, Maria Helena Pereira Toledo. História e historiografia da escravidão e da abolição em São Paulo. In: FERREIRA, Antonio Celso; LUCA, Tânia Regina de; IOKOI, Zilda Grícoli (Orgs.). Encontros com a História: percursos históricos e historiográficos de São Paulo. São Paulo: UNESP, 1999. p. 61-70.

MACHADO, Maria Helena. O plano e o pânico: os movimentos sociais da década da abolição. São Paulo: EDUSP, 1994.

MARTINS, Ana Luiza; BARBUY, Heloisa. Arcadas: história da Faculdade de Direito do Largo de São Francisco 1827-1997. São Paulo: Alternativa, 1998.

NEQUETE, Lenine. O escravo na jurisprudência brasileira: magistratura e ideologia no segundo reinado. Porto Alegre: Tribunal de Justiça do Rio Grande do Sul, 1988.

POMPÉIA, Raul. Última página da vida de um grande homem. In: SILVA, Edmar, et al. Luiz Gama: poeta e cidadão, memória da luta negra em São Paulo. São Paulo: Prefeitura Municipal Coordenadoria Especial dos Assuntos da População Negra, 2003. p. 32-40.

SANTOS, Francisco Martins dos. História de Santos. 2. ed. São Vicente: Caudex, 1986.

VENANCIO FILHO, Alberto. Das Arcadas ao bacharelismo: 150 anos de ensino no Brasil. São Paulo: Perspectivas, 1977. p. 41.

VIDA e Obra de Bernardo Guimarães - poeta e romancista brasileiro [1825-1884 - biografia]. < http:// www.geocities.com/athens/olympus/3583/ambrosio.htm>. Acesso em: 11 dez. 2008. 